\title{
Crescentic glomerular nephritis associated with rheumatoid arthritis: a case report
}

\author{
K. Balendran ${ }^{1 *}$ D, L. D. S. U. Senarathne ${ }^{1}$ and R. D. Lanerolle $e^{1,2}$
}

\begin{abstract}
Background: Rheumatoid arthritis is a systemic disorder where clinically significant renal involvement is relatively common. However, crescentic glomerular nephritis is a rarely described entity among the rheumatoid nephropathies. We report a case of a patient with rheumatoid arthritis presenting with antineutrophil cytoplasmic antibody-negative crescentic glomerular nephritis.

Case presentation: A 54-year-old Sri Lankan woman who had recently been diagnosed with rheumatoid arthritis was being treated with methotrexate $10 \mathrm{mg}$ weekly and infrequent nonsteroidal anti-inflammatory drugs. She presented to our hospital with worsening generalized body swelling and oliguria of 1 month's duration. Her physical examination revealed that she had bilateral pitting leg edema and periorbital edema. She was not pale or icteric. She had evidence of mild synovitis of the small joints of the hand bilaterally with no deformities. No evidence of systemic vasculitis was seen. Her blood pressure was 170/100 $\mathrm{mmHg}$, and her jugular venous pressure was elevated to $7 \mathrm{~cm}$ with an undisplaced cardiac apex. Her urine full report revealed 2+ proteinuria with active sediment (dysmorphic red blood cells [17\%] and granular casts). Her 24-hour urinary protein excretion was $2 \mathrm{~g}$. Her serum creatinine level was $388 \mu \mathrm{mol} / \mathrm{L}$. Abdominal ultrasound revealed normal-sized kidneys with acute parenchymal changes and mild ascites. Her renal biopsy showed renal parenchyma containing 20 glomeruli showing diffuse proliferative glomerular nephritis, with 14 of 20 glomeruli showing cellular crescents, and the result of Congo red staining was negative. Her rheumatoid factor was positive with a high titer $(120 \mathrm{IU} / \mathrm{ml})$, but results for antinuclear antibody, double-stranded deoxyribonucleic acid, and antineutrophil cytoplasmic antibody (perinuclear and cytoplasmic) were negative. Antistreptolysin $\mathrm{O}$ titer $<200 \mathrm{U} / \mathrm{ml}$ and cryoglobulins were not detected. The results of her hepatitis serology, retroviral screening, and malignancy screening were negative. Her erythrocyte sedimentation rate was $110 \mathrm{~mm}$ in the first hour, and her C-reactive protein level was $45 \mathrm{mg} / \mathrm{dl}$. Her liver profile showed hypoalbuminemia of $28 \mathrm{~g} / \mathrm{dl}$. She was treated with immunomodulators and had a good recovery of her renal function.

Conclusions: This case illustrates a rare presentation of antineutrophil cytoplasmic antibody-negative crescentic glomerular nephritis in a patient with rheumatoid arthritis, awareness of which would facilitate early appropriate investigations and treatment.
\end{abstract}

Keywords: Crescentic glomerular nephritis, Rheumatoid nephropathies, Rheumatoid arthritis

\section{Background}

Rheumatoid arthritis is a systemic disorder that primarily affects the joints, but renal involvement is relatively common and clinically significant because it worsens the course and mortality of the primary disease [1]. Renal involvement in rheumatoid arthritis includes secondary amyloidosis, nephrotoxicity of the drugs used for

\footnotetext{
* Correspondence: karthihabalendran@gmail.com

'University Medical Unit, National Hospital of Sri Lanka, Colombo 10,

Colombo, Sri Lanka

Full list of author information is available at the end of the article
}

treatment, and rheumatoid nephropathy as extra-articular manifestations [1-5]. In rheumatoid nephropathies, mesangial glomerular nephritis is the most frequent histological lesion, followed by minimal change glomerulopathy, membranous glomerulopathy, and crescentic glomerular nephritis $[1,2,6-10]$. Crescentic glomerular nephritis is rare, and more than $50 \%$ of the patients have features of systemic vasculitis, with almost all having perinuclear antineutrophil cytoplasmic antibody positivity $[9,10]$. Only one case of rheumatoid arthritis-associated antineutrophil cytoplasmic antibody (ANCA)-negative crescentic glomerular nephritis 
has been reported to date [10]. We report a case of a patient with rheumatoid arthritis who presented with ANCA-negative crescentic glomerular nephritis without frank systemic vasculitis.

\section{Case presentation}

A 54-year-old Sri Lankan woman who had recently been diagnosed with rheumatoid arthritis presented to our hospital with worsening bilatateral leg swelling and facial puffiness of 1 month's duration, accompanied by oliguria. She had no frothy urine or hematuria. She did not have exertional breathlessness or orthopnea, and she had no history suggestive of a cardiac or hepatic cause of edema. She was not diabetic or hypertensive. Her rheumatoid arthritis had been diagnosed 8 months earlier, when she presented with bilateral symmetrical polyarthritis involving the small joints of her hands with significant morning stiffness of 2 hours' duration. Her rheumatoid factor was positive at a high titer. She was commenced on methotrexate $10 \mathrm{mg}$ weekly and infrequent nonsteroidal anti-inflammatory drugs, with good symptom control achieved.

Her physical examination revealed that she had bilateral pitting leg edema and periorbital edema. She was not pale or icteric. No malar rash, vasculitic rash, or distal gangrene was seen. She had evidence of mild synovitis of the small joints of the hands bilaterally with no deformities. No generalized lymphadenopathy or hepatosplenomegaly was noted. Her pulse rate was 90 beats per minute; her blood pressure was 170/100 $\mathrm{mmHg}$; and her jugular venous pressure was elevated to $7 \mathrm{~cm}$ with an undisplaced cardiac apex and normal heart sounds. A fundus

Table 1 Patient's laboratory examination results

\begin{tabular}{|c|c|}
\hline Examinations & Results \\
\hline Urine full report & Protein 2+ Pus cells: 5-10/HPF Red blood cells: moderately full field Few granular casts present \\
\hline Twenty-four-hour urinary protein excretion & $2 \mathrm{~g} / 24$ hours \\
\hline Dysmorphic red blood cells & $17 \%$ \\
\hline Serum creatinine & 2 months before presentation: $88 \mu \mathrm{mol} / \mathrm{L}$ \\
\hline \multirow[t]{2}{*}{ Serum electrolytes } & Sodium: $138 \mathrm{mmol} / \mathrm{L}$ \\
\hline & Potassium: $4.1 \mathrm{mmol} / \mathrm{L}$ \\
\hline \multirow[t]{2}{*}{ Inflammatory markers } & ESR: $110 \mathrm{~mm}$ in first hour \\
\hline & CRP: $45 \mathrm{mg} / \mathrm{dl}$ \\
\hline Fasting blood sugar & $95 \mathrm{mg} / \mathrm{dl}$ \\
\hline Abdominal ultrasound & $\begin{array}{l}\text { Normal-sized kidneys with acute parenchymal changes and mild ascites } \\
\text { No organomegaly }\end{array}$ \\
\hline Renal biopsy & $\begin{array}{l}\text { Renal parenchyma containing } 20 \text { glomeruli showing diffuse proliferative glomerular nephritis, } \\
\text { with } 14 \text { of } 20 \text { glomeruli showing cellular crescents, and result of Congo red staining was negative } \\
\text { Immune fixation not done, owing to its unavailability }\end{array}$ \\
\hline \multirow[t]{7}{*}{ Immunological markers } & Rheumatoid factor: high titer (120 IU/ml) \\
\hline & ANA- and dsDNA-negative \\
\hline & ANCA-negative (perinuclear and cytoplasmic) \\
\hline & Complement C3: 98 mg/dl (normal range 90-180) \\
\hline & Complement C4: 21 mg/dl (normal range 10-40) \\
\hline & ASOT: $<200 \mathrm{U} / \mathrm{ml}$ \\
\hline & Cryoglobulins: not detected \\
\hline \multirow[t]{5}{*}{ Other secondary causes screening } & Hepatitis B surface antigen-negative \\
\hline & Hepatitis C antibody-negative \\
\hline & HIV-1- and HIV-2-negative \\
\hline & Malignancy screening: negative \\
\hline & $\begin{array}{l}\text { Screening tests done: chest } x \text {-ray, ultrasound thyroid, abdomen and pelvis, mammogram, } \\
\text { gastrointestinal endoscopy }\end{array}$ \\
\hline \multirow[t]{2}{*}{ Liver profile } & $\begin{array}{l}\text { Albumin: } 28 \mathrm{~g} / \mathrm{L} \\
\text { Globulin: } 33 \mathrm{~g} / \mathrm{L}\end{array}$ \\
\hline & Transaminases and bilirubin: normal \\
\hline
\end{tabular}


examination did not reveal papilledema. Her lungs were clear with equal breath sounds bilaterally. The results of the rest of the examination were normal. Her laboratory investigation results are provided in Table 1.

A diagnosis of crescentic glomerular nephritis was made. The patient was started on atorvastatin, enalapril, and diuretics. Intravenous methylprednisolone $1 \mathrm{~g}$ was given for 3 consecutive days, followed by $1 \mathrm{mg} / \mathrm{kg}$ oral prednisolone. She was started on intravenous cyclophosphamide $500 \mathrm{mg}$ every 2 weeks for a total of six doses. She gradually had increasing urine output and was symptomatically better, with improving renal function. Her serum creatinine level was $110 \mu \mathrm{mol} / \mathrm{L}$ at her last clinic visit after 3 months of treatment.

\section{Discussion}

A middle-aged woman with seropositive rheumatoid arthritis presented to our hospital with progressively worsening generalized edema with features of intravascular volume overload. Investigations revealed a subnephrotic range of proteinuria with active sediment and impaired renal function with histological evidence of crescentic glomerular nephritis.

Because crescentic glomerular nephritis is a rare entity in rheumatoid nephropathy, we looked for other causes of crescentic glomerular nephritis. Our patient did not have clinical features of systemic vasculitis. Her antibody profile was negative for systemic lupus erythematosus, medium-vessel vasculitis, and cryoglobulinemia. Also, the result of her solid organ malignancy screening was negative. She was treated with methylprednisolone and cyclophosphamide pulses and had good recovery of her renal function.

Crescentic glomerulonephritis is a rarely described entity [11-13]. These patients generally present with microscopic hematuria, proteinuria, and renal impairment, as seen in our patient. It is usually associated with seropositive erosive disease with a median duration of arthritis of 12 years (range 1-25 years) [11]. However, our patient presented within 1 year of receiving her seropositive rheumatoid arthritis diagnosis and did not have erosive arthritis. To the best of our knowledge, only one case of rheumatoid arthritis-associated ANCA-negative crescentic glomerular nephritis has been reported to date [10]. Crescentic glomerular nephritis needs aggressive treatment with immunomodulators, including intravenous methylprednisolone pulses and cyclophosphamide [14].

\section{Conclusions}

Crescentic glomerular nephritis without systemic vasculitis as an extra-articular manifestation in rheumatoid arthritis is rare but has severe clinical manifestations. Early diagnosis and treatment are vital.
Abbreviations

ANA: Antinuclear antibody; ANCA: Antineutrophil cytoplasmic antibody; ASOT: Antistreptolysin O titer; CRP: C-reactive protein; dsDNA: Double-stranded DNA; ESR: Erythrocyte sedimentation rate; HPF: High-power field

Acknowledgements

Not applicable.

Funding

Not applicable.

Availability of data and materials

Not applicable.

\section{Authors' contributions}

RDL was the primary physician (consultant nephrologist) who cared for the patient. KB and LDSUS were involved in patient care and contributed academically. KB wrote the manuscript. RDL critically revised the manuscript. All authors read and approved the final manuscript.

\section{Competing interests}

The authors declare that they have no competing interests.

\section{Consent for publication}

Written informed consent was obtained from the patient for publication of this case report. A copy of the written consent is available for review by the Editor-in-Chief of this journal.

Ethics approval and consent to participate

Not applicable.

\section{Publisher's Note}

Springer Nature remains neutral with regard to jurisdictional claims in published maps and institutional affiliations.

\section{Author details}

${ }^{1}$ University Medical Unit, National Hospital of Sri Lanka, Colombo 10, Colombo, Sri Lanka. ²Department of Clinical Medicine, University of Colombo, Colombo, Sri Lanka.

Received: 26 February 2017 Accepted: 30 May 2017 Published online: 21 July 2017

\section{References}

1. Icardi A, Araghi P, Ciabattoni M, Romano U, Lazzarini P, Bianchi G. Kidney involvement in rheumatoid arthritis [in Italian]. Reumatismo. 2003;55(2):76-85.

2. Galesić K, Prkacin I, Tisljar M, Vergles JM. Renal involvement in patients with rheumatoid arthritis [in Croatian]. Reumatizam. 2009;56(1):30-5.

3. Raczkiewicz A, Nowak Z, Tłustochowicz W. Renal involvement in rheumatoid arthritis. Reumatologia. 2014;52(5):311-31.

4. Adu D, Berisa F, Howie AJ, Emery P, Bacon PA, McConkey B, et al. Glomerulonephritis in rheumatoid arthritis. Br J Rheumatol. 1993;32(11):1008-11.

5. Karie S, Gandjbakhch F, Janus N, Launay-Vacher V, Rozenberg S, Mai Ba CU, et al. Kidney disease in RA patients: prevalence and implication on RA-related drugs management: the MATRIX study. Rheumatology (Oxford). 2008;47(3):350-4.

6. Irie F, Kobayashi M, Hirayama K, Nagase S, litsuka T, Yamaguchi N, et al. Rheumatoid arthritis associated with membranous nephropathy and IgA nephritis with necrotizing lesions. Nephrol Dial Transplant. 1996;11(7):1338-41.

7. Makino H, Yoshinaga Y, Yamasaki Y, Morita Y, Hashimoto H, Yamamura M. Renal involvement in rheumatoid arthritis: analysis of renal biopsy specimens from 100 patients. Mod Rheumatol. 2002;12(2):148-54.

8. Korpela M, Mustonen J, Teppo AM, Helin H, Pasternack A. Mesangial glomerulonephritis as an extra-articular manifestation of rheumatoid arthritis. Br J Rheumatol. 1997;36(11):1189-95.

9. Kurita N, Mise N, Fujii A, Mori M, Sai K, Nishi T, et al. Myeloperoxidaseantineutrophil cytoplasmic antibody-associated crescentic glomerulonephritis with rheumatoid arthritis: a comparison of patients without rheumatoid arthritis. Clin Exp Nephrol. 2010;14(4):325-32.

10. Hsieh HS, Chang CF, Yang AH, Kuo HL, Yang WC, Lin CC. Antineutrophil cytoplasmic antibody-negative pauci-immune crescentic glomerulonephritis 
associated with rheumatoid arthritis: an unusual case report. Nephrology (Carlton). 2003;8(5):243-7.

11. Aggarwal P, Aggarwal A, Dhingira S, Misra R. Renal involvement in rheumatoid arthritis: a case report and review of literature. J Indian Rheumatol Assoc. 2004;12:70-3.

12. Min KO, Choi YJ, Kim BK, Kim SM, Shim SI. Crescentic glomerulonephritis in a patient with rheumatoid arthritis: a case report. Korean J Pathol. 1995;29(1):116-8.

13. Nakamura T, Arima S, Tsuruta T, Matsubara S, Sakaguchi M, Wakamatsu S, et al. Crescentic glomerulonephritis in a patient with rheumatoid arthritis [in Japanese]. Ryumachi. 1997;37(3):476-82.

14. Kidney Disease: Improving Global Outcomes (KDIGO) Glomerulonephritis Work Group. KDIGO Clinical Practice Guideline for Glomerulonephritis. Kidney Int Suppl. 2012;2:139-274.

Submit your next manuscript to BioMed Central and we will help you at every step:

- We accept pre-submission inquiries

- Our selector tool helps you to find the most relevant journal

- We provide round the clock customer support

- Convenient online submission

- Thorough peer review

- Inclusion in PubMed and all major indexing services

- Maximum visibility for your research

Submit your manuscript at www.biomedcentral.com/submit
Biomed Central 